\title{
Group 12 complexes of 2,6-bis([(2-pyridinylmethyl)thio]methyl)pyridine: Synthesis and characterization by X-ray crystallography and Proton NMR
}

Bradley J. Carra, Stephanie N. Till, Robert A. VanGundy, Robert D. Pike, Deborah C. Bebout*

Keywords: Group 12; N, S Ligand; Conformation; X-ray crystallography; NMR spectroscopy 


\section{Introduction}

One of the motivations for comparing the coordination behavior of the Group 12 metal ions with a single ligand is to gain insight regarding their fascinating differences in bioactivity. Functionally, zinc(II) has more physiological diversity than any other essential metal ion, yet sufficient reactivity in free form to warrant tight regulation.[1-4] Both $\mathrm{Hg}(\mathrm{II})$ [5] and $\mathrm{Cd}(\mathrm{II})$ [6] have multifaceted toxicity, however some microorganisms transcribe a gene encoding a cadmium-containing carbonic anhydrase to contend with marine $\mathrm{Zn}(\mathrm{II})$-depletion.[7, 8] Developing a fundamental understanding of the bioactivity differences between divalent Group 12 metal ions has been hindered by rapid exchange processes and limited spectroscopic handles.

Replacement of native metal ions in preorganized protein metal binding sites continues to be an active area of heavy metal toxicity research.[9] Recent studies have also provided evidence for altering overall protein structure through the interactions of Group 12 metal ions with accessible functional groups in nascent and non-native forms.[10] For example, $\mathrm{Zn}$ (II) and Ni(II) have comparable affinities for the unstructured histidine- and cysteine-rich sequences of nickel chaperones[11], suggesting a disruptive role for zinc in nickel homeostasis.[12] In addition, $\mathrm{Hg}(\mathrm{II})$-exposure induced a $\beta$-turn structure into the natively unstructured Alzheimer's disease tau construct R3 in vitro,[13] possibly revealing a metal-dependent trigger to the aggregation associated with the pathological positive feedback circle of Alzheimer's disease.[14] In contrast, $\mathrm{Cd}(\mathrm{II})$ counteracts amyloid $\beta$-peptide 1-42 aggregation in solution.[15] Interestingly, the distribution of structural states for a peptide model of zinc finger proteins was metal-dependent when exposed to substoichiometric amounts of $\mathrm{Zn}(\mathrm{II}), \mathrm{Cd}(\mathrm{II})$ or $\mathrm{Hg}(\mathrm{II})$.[16] Significantly, histidine and methionine are common amino acids in unstructured metal binding regions of proteins associated with neurodegenerative diseases[12] and the mechanisms underlying cadmium[17] and mercury[18] neurotoxicity remain elusive despite considerable research. 
These intriguing studies have prompted comparative studies of Group 12 metal ion coordination with multidentate ligand systems, with the goal of analyzing how the ensemble of ligand conformations varied under similar conditions for the three metal ions. Although the $\mathrm{d}^{10}$ Group 12 metal ions tolerate a wide range of coordination numbers and coordination geometries with simple ligands, multidentate ligands can be effective at limiting intermolecular ligand exchange.[19-22] Furthermore, the facile intramolecular isomerization commonly observed for mononuclear Group 12 complexes,[19, 23] has been suppressed with the pentadentate ligand $\mathbf{L}^{\prime}$.[24] This paper describes the first solid- and solution-state investigation of all three divalent Group 12 metal ions with a single ligand providing an $\mathrm{N}_{3} \mathrm{~S}_{2}$ set of donor atoms. Known acyclic ligand 2,6-bis([(2-pyridinylmethyl)thio]methyl)pyridine (L) provides a combination of aromatic nitrogen and thioether donors capable of forming four fused chelate rings.[25] Commercially available perchlorate salts were used because of their demonstrated abilities to form complexes with the inter- and intramolecular exchange properties suitable for ${ }^{1} \mathrm{H}$ NMR studies with related ligands.[24] Herein, we show that nearly symmetric $[\mathrm{ZnL}]\left(\mathrm{ClO}_{4}\right)_{2}(\mathbf{1})$ and symmetric $[\mathrm{HgL}]\left(\mathrm{ClO}_{4}\right)_{2}(\mathbf{3})$ have very similar conformations of $\mathbf{L}$ and well-separated perchlorates. In contrast, a bidentate perchlorate in $\left[\mathrm{Cd} \mathbf{L}\left(\mathrm{ClO}_{4}\right)\right]\left(\mathrm{ClO}_{4}\right)(2)$ produced a new complex with biscapped square pyramidal coordination geometry. Proton NMR spectroscopy is used to investigate intermolecular ligand exchange and intramolecular ligand reorganization processes.

\section{Experimental}

\subsection{Materials and physical measurements.}

Starting materials were of commercially available reagent quality. The perchlorate complexes included in this work were stable for routine synthesis and purification procedures. However, caution should be exercised because perchlorate salts of metal complexes with organic 
ligands are potentially explosive.[26, 27] Elemental analyses were carried out by Atlantic Microlab, Inc., Norcross, Georgia. X-ray diffraction data were collected on a Bruker SMART Apex II three-circle diffractometer system with graphite monochromator, $\mathrm{Cu} \mathrm{K} \alpha$ fine-focus sealed tube $(\lambda=1.54178 \AA)$ and CCD detector using $\varphi$ and $\omega$ scans. Selected crystallographic data are given in Tables 1 and 2. The structures were solved by direct methods or intrinsic phasing using the SHELXTL program package and refined on $\mathrm{F}^{2}$ by full-matrix least squares using the SHELXle program package.[28, 29] All non-hydrogen atoms were refined anisotropically; the hydrogen atomic positions were fixed as riding to the bonded carbons with fixed isotropic thermal parameters. Proton NMR spectra were collected in $5 \mathrm{~mm}$ o.d. NMR tubes on a Varian Mercury 400VX NMR or Agilent 400-MR DD2 NMR spectrometer operating in the pulse Fourier transform mode. Calibrated autopipets were used to prepare nominally $2 \mathrm{mM}$ solutions for variable temperature NMR measurements by dissolution of elementally analyzed complexes. The sample temperature was maintained by blowing chilled nitrogen over the NMR tube in the probe. Proton chemical shifts were measured relative to internal solvent but are reported relative to tetramethylsilane (TMS). All coupling constants are reported in $\mathrm{Hz}$ and $J_{\mathrm{HH}}$ unless otherwise noted. Line fit analysis was performed using NUTS - NMR Utility Transform Software 1D Version 1.0.0.1 for Windows 95/NT.

\subsection{Synthesis of the compounds}

\subsubsection{Synthesis of 2,6-Bis([(2-pyridylmethyl)thio]methyl)pyridine $(\boldsymbol{L})$.}

The ligand was prepared by variation of the procedure described by Newkome and coworkers.[25] Picolyl chloride hydrochloride (1.0 g, $6.2 \mathrm{mmol})$ was added to a solution of 2,6pyridinedimethanethiol $(514 \mathrm{mg}, 3.0 \mathrm{mmol})$ and $\mathrm{NaOH}(500 \mathrm{mg}, 12.5 \mathrm{mmol})$ in $70 \% \mathrm{EtOH}(25$ 
$\mathrm{mL}$ ). The reaction mixture was refluxed under argon with stirring for 2.5 hours, cooled, and the solvent removed in vacuo. The brown residue was extracted with chloroform $(3 \times 20 \mathrm{~mL})$. The combined organics were dried over $\mathrm{Na}_{2} \mathrm{SO}_{4}$ and concentrated in vacuo. Alumina chromotagraphy using 1:1 ethyl acetate:hexane as the mobile phase provide $\mathbf{L}$ as a viscous yellow oil (757 $\mathrm{mg}$, $71 \%$ ). Overnight suffusion with a few drops of acetonitrile provided an off-white crystalline material. X-ray quality needles were obtained by slow diffusion of pentane into a concentrated toluene solution of $\mathbf{L}$. MP $57.8-59.0^{\circ} \mathrm{C} .{ }^{1} \mathrm{H}$ NMR $\left(\mathrm{CDCl}_{3}\right) \delta 8.54\left(\mathrm{~d}, 2 \mathrm{H},{ }^{3} J_{\mathrm{HH}}=5 \mathrm{~Hz}, \mathrm{H}_{\mathrm{a}}\right), 7.62$ $\left(\mathrm{dt}, 2 \mathrm{H},{ }^{3} J_{\mathrm{HH}}=8,{ }^{4} J_{\mathrm{HH}}=2, \mathrm{H}_{\mathrm{c}}\right), 7.58\left(\mathrm{t}, 1 \mathrm{H},{ }^{3} J_{\mathrm{HH}}=8, \mathrm{H}_{\mathrm{h}}\right), 7.39\left(\mathrm{~d}, 2 \mathrm{H},{ }^{3} J_{\mathrm{HH}}=8, \mathrm{H}_{\mathrm{d}}\right), 7.24(\mathrm{~d}, 2 \mathrm{H}$, $\left.{ }^{3} J_{\mathrm{HH}}=8, \mathrm{H}_{\mathrm{g}}\right), 7.15\left(\mathrm{dd}, 2 \mathrm{H},{ }^{3} J_{\mathrm{HH}}=8,5, \mathrm{H}_{\mathrm{b}}\right), 3.84\left(\mathrm{~s}, 4 \mathrm{H}, \mathrm{pyCH}_{2}\right), 3.80\left(\mathrm{~s}, 4 \mathrm{H}, \mathrm{pyCH}_{2}\right) ;\left(\mathrm{CD}_{3} \mathrm{CN}\right)$ $\delta 8.47\left(\mathrm{ddd}, 2 \mathrm{H},{ }^{3} J_{\mathrm{HH}}=4.9 \mathrm{~Hz},{ }^{4} J_{\mathrm{HH}}=0.9,2.0 \mathrm{~Hz} \mathrm{H} \mathrm{H}_{\mathrm{a}}\right), 7.70\left(\mathrm{dt}, 2 \mathrm{H},{ }^{3} J_{\mathrm{HH}}=7.9,{ }^{4} J_{\mathrm{HH}}=1.9, \mathrm{H}_{\mathrm{c}}\right)$, $7.63\left(\mathrm{t}, 1 \mathrm{H},{ }^{3} J_{\mathrm{HH}}=7.7, \mathrm{H}_{\mathrm{h}}\right), 7.39\left(\mathrm{~d}, 2 \mathrm{H},{ }^{3} J_{\mathrm{HH}}=7.9,{ }^{4} J_{\mathrm{HH}}=1.8 \mathrm{~Hz}, \mathrm{H}_{\mathrm{d}}\right), 7.24\left(\mathrm{~d}, 2 \mathrm{H},{ }^{3} J_{\mathrm{HH}}=7.8\right.$, $\left.\mathrm{H}_{\mathrm{g}}\right), 7.19\left(\mathrm{ddd}, 2 \mathrm{H},{ }^{3} J_{\mathrm{HH}}=7.6,4.9,{ }^{4} J_{\mathrm{HH}}=1.0 \mathrm{~Hz}, \mathrm{H}_{\mathrm{b}}\right), 3.82\left(\mathrm{~s}, 4 \mathrm{H}, \mathrm{CH}_{2}\right), 3.77\left(\mathrm{~s}, 4 \mathrm{H}, \mathrm{CH}_{2}\right)$.

\subsubsection{Preparation and characterization of $[\mathrm{ZnL}]\left(\mathrm{ClO}_{4}\right)_{2}(\mathbf{1})$.}

An acetonitrile $(1.5 \mathrm{~mL})$ solution of vacuum dried $\mathrm{Zn}\left(\mathrm{ClO}_{4}\right)_{2} \cdot 6 \mathrm{H}_{2} \mathrm{O}(26 \mathrm{mg}, 71 \mu \mathrm{mol})$ was mixed with a solution of $\mathbf{L}(25 \mathrm{mg}, 71 \mu \mathrm{mol})$ in $0.5 \mathrm{~mL}$ acetonitrile and $m$-xylene ( $5 \mathrm{~mL})$ was added rapidly dropwise. Vacuum filtration and drying provided $\mathbf{1}$ as a white precipitate (39 $\mathrm{mg}, 63 \mu \mathrm{mol}, 89 \%$ yield). Clear, colorless crystals suitable for X-ray diffraction were obtained by slow evaporation from acetonitrile/m-xylene. m.p.: $>260{ }^{\circ} \mathrm{C} .{ }^{1} \mathrm{H} \mathrm{NMR}\left(\operatorname{dry} \mathrm{CD}_{3} \mathrm{CN}, 2 \mathrm{mM}\right.$, $\left.20^{\circ} \mathrm{C}\right) \delta 8.681\left(\mathrm{~d}, 2 \mathrm{H},{ }^{3} J_{\mathrm{HH}}=5.5, \mathrm{H}_{\mathrm{a}}\right), 8.126\left(\mathrm{ddd}, 2 \mathrm{H},{ }^{3} J_{\mathrm{HH}}=7.9,7.9,{ }^{4} J_{\mathrm{HH}}=1.2 \mathrm{~Hz}, \mathrm{H}_{\mathrm{c}}\right), 8.032$

$\left(\mathrm{t}, 1 \mathrm{H},{ }^{3} J_{\mathrm{HH}}=7.8, \mathrm{H}_{\mathrm{h}}\right), 7.698\left(\mathrm{~d}, 2 \mathrm{H},{ }^{3} J_{\mathrm{HH}}=8.0, \mathrm{H}_{\mathrm{d}}\right), 7.639\left(\mathrm{dd}, 2 \mathrm{H},{ }^{3} J_{\mathrm{HH}}=7.6,5.6, \mathrm{H}_{\mathrm{b}}\right), 7.572$ $\left(\mathrm{d}, 2 \mathrm{H},{ }^{3} \mathrm{~J}_{\mathrm{HH}}=7.8, \mathrm{H}_{\mathrm{g}}\right), 4.494$ (bs, $\left.8 \mathrm{H}, \mathrm{CH}_{2}\right)$. Elemental Analysis $\mathrm{C}_{19} \mathrm{H}_{19} \mathrm{Cl}_{2} \mathrm{~N}_{3} \mathrm{O}_{8} \mathrm{~S}_{2} \mathrm{Zn}$ : calculated $36.95 \% \mathrm{C}, 3.10 \% \mathrm{H}, 6.80 \% \mathrm{~N}$; found $36.81 \% \mathrm{C}, 3.03 \% \mathrm{H}, 6.76 \% \mathrm{~N}$.

\subsubsection{Preparation and characterization of $\left[\mathrm{Cd} \mathbf{L}\left(\mathrm{ClO}_{4}\right)\right]\left(\mathrm{ClO}_{4}\right)(2)$.}


An acetone $(3 \mathrm{~mL})$ solution of vacuum dried $\mathrm{Cd}\left(\mathrm{ClO}_{4}\right)_{2} \cdot 6 \mathrm{H}_{2} \mathrm{O}(36 \mathrm{mg}, 86 \mu \mathrm{mol})$ was added to a solution of $\mathbf{L}$ ( $31 \mathrm{mg}, 88 \mu \mathrm{mol})$ in $1 \mathrm{~mL}$ acetone. The solution was filtered through celite, partitioned into $1 \mathrm{~mL}$ aliquots and layered with ether for slow diffusion. Yellow crystals suitable for X-ray diffraction formed overnight (36 mg, $54 \mu \mathrm{mol}, 62 \%$ ). m.p.: $189^{\circ} \mathrm{C}$ (dec.). ${ }^{1} \mathrm{H}$ NMR (acetonitrile- $\left.d_{3}, 2 \mathrm{mM}, 20^{\circ} \mathrm{C}\right) \delta 8.603\left(\mathrm{bd}, 2 \mathrm{H},{ }^{3} J_{\mathrm{HH}}=5.1, \mathrm{H}_{\mathrm{a}}\right), 8.006\left(\mathrm{ddd}, 2 \mathrm{H},{ }^{3} J_{\mathrm{HH}}=7.6,7.6\right.$, $\left.{ }^{4} J_{\mathrm{HH}}=1.4, \mathrm{H}_{\mathrm{c}}\right), 7.696\left(\mathrm{t}, 1 \mathrm{H},{ }^{3} J_{\mathrm{HH}}=7.8, \mathrm{H}_{\mathrm{h}}\right), 7.612\left(\mathrm{~d}, 2 \mathrm{H},{ }^{3} J_{\mathrm{HH}}=7.8, \mathrm{H}_{\mathrm{d}}\right), 7.525\left(\mathrm{dd}, 2 \mathrm{H},{ }^{3} J_{\mathrm{HH}}=\right.$ 5.5, 7.7, $\left.\mathrm{H}_{\mathrm{b}}\right), 7.234\left(\mathrm{~d}, 2 \mathrm{H},{ }^{3} J_{\mathrm{HH}}=7.7, \mathrm{H}_{\mathrm{g}}\right), 4.422\left(\mathrm{bs}, \mathrm{CH}_{2}\right), 4.127\left(\mathrm{bs}, \mathrm{CH}_{2}\right)$. Elemental Analysis $\mathrm{C}_{19} \mathrm{H}_{19} \mathrm{CdCl}_{2} \mathrm{~N}_{3} \mathrm{O}_{8} \mathrm{~S}_{2}$ : calculated $34.34 \% \mathrm{C}, 2.88 \% \mathrm{H}, 6.32 \% \mathrm{~N}$; found $34.42 \% \mathrm{C}, 2.88 \% \mathrm{H}$, $6.28 \% \mathrm{~N}$.

\subsubsection{Preparation and characterization of $[\mathrm{HgL}]\left(\mathrm{ClO}_{4}\right)_{2}(3)$.}

An acetonitrile $(1.5 \mathrm{~mL})$ solution of vacuum dried $\mathrm{Hg}\left(\mathrm{ClO}_{4}\right)_{2} \cdot 3 \mathrm{H}_{2} \mathrm{O}(32 \mathrm{mg}, 71 \mu \mathrm{mol})$ was mixed with a solution of $\mathbf{L}(25 \mathrm{mg}, 71 \mu \mathrm{mol})$ in $0.5 \mathrm{~mL}$ acetonitrile and $m$-xylene $(5 \mathrm{~mL})$ was added rapidly dropwise with stirring. Vacuum filtration and drying provided $\mathbf{3}$ as a white precipitate (42 mg, $56 \mu \mathrm{mol}, 78 \%$ ). Clear, colorless crystals were obtained by slow evaporation from acetonitrile $/ m$-xylene and slow diffusion of ether into a solution of $\mathbf{3}$ in acetonitrile. Crystals were all twinned or modest diffractors. An acceptable structure was obtained in orthorhombic space group $I b c a$ at room temperature (Table 1). Upon cooling to $200 \mathrm{~K}$, the crystal underwent a reversible phase change from a body centered to primitive orthorhombic cell with doubling of the $b$ axis and unit cell volume (Pbcn; $a=29.5816(4) ; \mathrm{b}=13.6908(2) \AA ; c=$ 23.9607(3) $\AA ; \alpha=\beta=\gamma=90 ; V=9704.0(2) \AA^{3} ; \mathrm{Z}=16$; see Table S1, Table S2 and Fig. S5). A further destructive phase change was observed between 200 and $100 \mathrm{~K}$. m.p.: $156{ }^{\circ} \mathrm{C}$ (dec.). ${ }^{1} \mathrm{H}$ $\operatorname{NMR}\left(\operatorname{dry~} \mathrm{CD}_{3} \mathrm{CN}, 2 \mathrm{mM}, 20{ }^{\circ} \mathrm{C}\right) \delta 8.714\left(\mathrm{bd}, 2 \mathrm{H},{ }^{3} \mathrm{~J}_{\mathrm{HH}}=5.4, \mathrm{H}_{\mathrm{a}}\right), 8.140\left(\mathrm{dd}, 2 \mathrm{H},{ }^{3} \mathrm{~J}_{\mathrm{HH}}=7.5\right.$, 7.5, $\left.\mathrm{H}_{\mathrm{c}}\right), 7.894\left(\mathrm{t}, 1 \mathrm{H},{ }^{3} J_{\mathrm{HH}}=7.8, \mathrm{H}_{\mathrm{h}}\right), 7.774\left(\mathrm{~d}, 2 \mathrm{H},{ }^{3} J_{\mathrm{HH}}=7.7, \mathrm{H}_{\mathrm{d}}\right), 7.693\left(\mathrm{bdd}, 2 \mathrm{H},{ }^{3} J_{\mathrm{HH}}=8.5\right.$, 


\author{
4.0, $\left.\mathrm{H}_{\mathrm{b}}\right), 7.441\left(\mathrm{~d}, 2 \mathrm{H},{ }^{3} \mathrm{~J}_{\mathrm{HH}}=7.8, \mathrm{H}_{\mathrm{g}}\right), 4.550\left(\mathrm{bs}, 4 \mathrm{H}, \mathrm{CH}_{2}\right), 4.337$ (bs, 4H, $\left.\mathrm{CH}_{2}\right)$. Elemental \\ Analysis $\mathrm{C}_{19} \mathrm{H}_{19} \mathrm{Cl}_{2} \mathrm{HgN}_{3} \mathrm{O}_{8} \mathrm{~S}_{2}$ : calculated $30.32 \% \mathrm{C}, 2.54 \% \mathrm{H}, 5.58 \% \mathrm{~N}$; found $30.37 \% \mathrm{C}$, \\ $2.45 \% \mathrm{H}, 5.51 \% \mathrm{~N}$.
}

\title{
3. Results \& Discussion
}

\subsection{Syntheses}

A viscous oil of 2,6-bis[((2-pyridylmethyl)thio)methyl]pyridine (L) was prepared according to the previously described method.[25] Suffusion with acetonitrile provided a crystalline material with identical ${ }^{1} \mathrm{H}$ NMR. Slow diffusion of pentane into a concentrated toluene solution of $\mathbf{L}$ provided needles suitable for X-ray crystallography.

The desired metal complexes were obtained by reaction of $\mathbf{L}$ with equimolar $\mathrm{Zn}\left(\mathrm{ClO}_{4}\right)_{2} \cdot 6$ $\mathrm{H}_{2} \mathrm{O}, \mathrm{Cd}\left(\mathrm{ClO}_{4}\right)_{2} \cdot 6 \mathrm{H}_{2} \mathrm{O}$ or $\mathrm{Hg}\left(\mathrm{ClO}_{4}\right)_{2} \cdot 3 \mathrm{H}_{2} \mathrm{O}$. X-ray quality crystals of $[\mathrm{ZnL}]\left(\mathrm{ClO}_{4}\right)_{2}(\mathbf{1})$ were prepared by slow evaporation from a solution of acetonitrile and $m$-xylene. Slow diffusion of ether into an equimolar acetone solution of $\mathrm{Cd}\left(\mathrm{ClO}_{4}\right)_{2} \cdot 6 \mathrm{H}_{2} \mathrm{O}$ and $\mathbf{L}$ provided X-ray quality crystals of $\left.\mathrm{CdL}\left(\mathrm{ClO}_{4}\right)\right] \mathrm{ClO}_{4}(\mathbf{2})$. Weakly diffracting crystals of $[\mathrm{HgL}]\left(\mathrm{ClO}_{4}\right)_{2}(3)$ were produced by both slow diffusion and slow evaporation methods with a variety of solvents. The three new complexes had satisfactory elemental analysis.

\subsection{Solid State Characterization}

The crystalline form of $\mathbf{L}$ had an extended puckered conformation (Fig. 1). The three pyridyl rings were roughly parallel to each other with the five heteroatoms aligned on one side of the molecule in the solid state. Herringbone crystal packing led to 2D supramolecular sheets with a variety of intermolecular $\sigma-\pi$ and offset $\pi-\pi$ interactions (Figure S1).

Crystallographic characterization of $\mathbf{1 , 2}$ and $\mathbf{3}$ provided the mononuclear cations shown in Figures 2 through 4, respectively. Selected bond distances and angles for these complexes are 
shown in Table 2. A disordered perchlorate in complex $\mathbf{1}$ was satisfactorily modeled using two positions of roughly equal occupancy. One of the perchlorates in $\mathbf{3}$ was seriously disordered in the room temperature structure motivating data collection at a lower temperature. The crystal underwent a reversible phase change on cooling to $200 \mathrm{~K}$ producing two crystallographically independent but nearly structurally identical molecules of 3 (Table S2).

In complex 1, the $\mathrm{Zn}(\mathrm{II})$ atom is five-coordinated in a distorted trigonal bipyramidal geometry $(\tau=0.64)$.[30] The three nitrogens of $\mathbf{L}$ form the equatorial plane and the ligand sulfurs occupy apical positions (Fig. 2). The two perchlorates are well-separated from the metal ion. While the complex does not have true $C_{2}$ symmetry, the $\mathrm{Zn}-\mathrm{N}$ bonds involving the terminal pyridyl nitrogens are comparable in length and approximately $0.07 \AA$ shorter than the one involving the central pyridyl. The two $\mathrm{Zn}-\mathrm{S}$ bonds are also comparable. The $[\mathrm{ZnL}]^{2+}$ complexes are connected by intermolecular edge-to-face $\sigma-\pi$ interactions between the N2 and N3 pyridyl rings with $4.95 \AA$ A between centroids, generating a 1D supramolecular chain extending along the b direction (Figure S2). The 1D chains are arranged into 2D sheets through offset parallel faceto-face $\pi-\pi$ interactions between pairs of N2 pyridyl rings with $4.71 \AA$ A between centroids.

In contrast, complex 2 has a seven coordinate Cd(II) atom (Fig. 3). Pentadentate $\mathbf{L}$ provides a distorted square pyramidal coordination environment $(\tau=0.32)$. A bidentate perchlorate caps the basal plan for an overall pentagonal bipyramidal coordination geometry with the terminal pyridyl nitrogens in apical positions. The second perchlorate is ordered and wellseparated from the metal ion. For comparison, $\tau=0.13$ for the five $\mathbf{L}$ donors in the chloride capped cations of previously reported $[\mathrm{CoLCl}]_{2}\left[\mathrm{CoCl}_{4}\right] \cdot 2 \mathrm{H}_{2} \mathrm{O} \cdot 2 \mathrm{MeOH}(4)$ ).[25] While longer M-S bond lengths in $\mathbf{2}$ than $\mathbf{1}$ could largely be accounted for by the larger van der Waals radius of cadmium (2.01 $\AA$ for $\mathrm{Zn}, 2.18 \AA$ for $\mathrm{Cd}$ ),[31] additional factors such as the higher 
coordination number are required to explain the longer M-N bonds in $\mathbf{2}$. The central pyridyl was notably canted from alignment with the $\mathrm{Cd}-\mathrm{N}$ bond (Cd1-N2-C10 angle $\left.134.7^{\circ}\right)$ in the solid state. As a result, the metal was $0.515 \AA$ from the S1N2S2 plane and the Cd-N2 bond was unusually long, permitting formation of 1D chains through intra- and intermolecular offset parallel face-to-face $\pi-\pi$ interactions to N1 pyridyl rings with $3.58 \AA$ and $4.35 \AA$ distances between centroids, respectively (Fig. S3). Two dimensional sheets are formed from these chains through offset parallel face-to-face $\pi-\pi$ interactions between pairs of N3 pyridyl rings with 3.89 $\AA$ centroid separations. Strong intraligand $\pi-\pi$ interactions were reported previously in $\left[\mathrm{Ag}_{3} \mathbf{L}_{2}\right]\left(\mathrm{NO}_{3}\right)_{3} .[32]$

Complex 3 has an $\mathrm{N}_{3} \mathrm{~S}_{2}$ metal coordination sphere with well-separated perchlorate ions, similar to complex 1 (Figure 3 ), but with a $C_{2}$ symmetric distorted square pyramidal geometry ( $\tau$ $=0.27$ ). The Hg-N2 bond length is $0.128 \AA$ longer than the Hg-N1 bond lengths in complex 3 . Intermolecular offset parallel face-to-face $\pi-\pi$ interactions between pairs of N1 pyridyl rings with $4.34 \AA$ A centroid separation were observed (Fig. S4). Upon cooling to $200 \mathrm{~K}$, this centroid separation shortened to $3.61 \AA$, likely contributing to the phase change observed (Fig. S5). In the room temperature structure, the $\mathrm{N} 2$ pyridyl rings are sandwiched between a pair of $\mathrm{N} 1$ pyridyl rings from adjacent molecules forming stabilizing intermolecular edge-to-face $\sigma-\pi$ interactions with a $4.97 \AA$ A centroid separation, generating a 2D sheet in the bc plane (Fig. S4).

Although the five M-L bonds provide metal coordination geometries in mononuclear cations with $\tau$ ranging from $0.13[25]$ to 0.64 , the ligand has a similar corkscrew conformation in the mononuclear cations of 1-4.The two terminal pyridyl nitrogen are involved in the largest $\mathrm{N}$ M-N bond angle amongst all four complexes, and this is the largest bond angle in complexes 2 and $\mathbf{4}$ where a capping ligand is located between the terminal pyridyl rings. The S-M-S bond 
angle is largest in complexes $\mathbf{1}$ and $\mathbf{3}$ and second largest in complex $\mathbf{2}$ and $\mathbf{4}$. An alternative ligand conformation with only one terminal pyridyl nitrogen displaced from the plane formed by the other four donor atoms has been observed for some metal ion complexes of $\mathbf{L}^{\prime}$. In the latter conformation, the largest N-M-N bond involved the central pyridyl nitrogen and one terminal pyridyl nitrogen.[24] The rigidity of the central portion of $\mathbf{L}$ and bulkiness of the terminal groups make other conformations unlikely for these types of ligands.[24]

\subsection{Solution State Characterization}

Solution ${ }^{1} \mathrm{H}$ NMR spectroscopy was used to investigate intermolecular exchange and intramolecular ligand reorganization processes for $\mathbf{L}$ with Group 12 perchlorate salts under similar conditions. Preliminary spectra were recorded for dilute solutions of $\mathbf{1}, \mathbf{2}$ and $\mathbf{3}$ in $\mathrm{CD}_{3} \mathrm{CN}$ (Fig. S6) and acetone- $d_{6}$ (data not shown) over the solvent accessible temperature ranges. Similarity of the ${ }^{1} \mathrm{H}$ NMR for the three complexes in the two solvents suggests solvent does not have a role in the dynamic behavior observed. Ligand protons were shifted downfield by the presence of each metal salt. The deshielding effects of $\mathrm{Zn}(\mathrm{II})$ and $\mathrm{Hg}(\mathrm{II})$ were comparable to each other and greater than those of $\mathrm{Cd}(\mathrm{II})$, as also observed for complexes of $\mathbf{L}^{\prime}$.

To investigate whether ligand dissociation contributed to differences in ${ }^{1} \mathrm{H}$ NMR peak width for $\mathbf{1}, \mathbf{2}$ and $\mathbf{3}$ (Fig. S6), titration of $\mathbf{L}$ with each metal salt was monitored by ${ }^{1} \mathrm{H}$ NMR spectroscopy.[33, 34] As shown in Figure 5, separate resonances are observed for each symmetry related pyridyl proton of $\mathbf{1}$ and free $\mathbf{L}$ at $20{ }^{\circ} \mathrm{C}$ in $\mathrm{CD}_{3} \mathrm{CN}$ when $\left[\mathrm{Zn}\left(\mathrm{ClO}_{4}\right)_{2}\right] /[\mathbf{L}]<1$, with no further change in proton chemical shift at modestly higher metal to ligand ratios. These observations are consistent with slow intermolecular exchange between $\mathbf{1}$ and excesses of either ligand or $\mathrm{Zn}\left(\mathrm{ClO}_{4}\right)_{2}$. Note that the two singlets for the methylene protons of $\mathbf{L}$ are replaced by 
one sharp singlet and one resonance broadened to obscurity as $\mathbf{1}$ is formed under these conditions, indicating an intramolecular reorganization process occurring on an intermediate rate relative to the chemical shift time scale. In contrast, solutions with $\left[\mathrm{Cd}\left(\mathrm{ClO}_{4}\right)_{2}\right] /[\mathbf{L}]<1$ and $\left[\mathrm{Hg}\left(\mathrm{ClO}_{4}\right)_{2}\right] /[\mathbf{L}]<1$ had a single resonance for each symmetry-related ligand proton with a chemical shift corresponding to a mole fraction weighted average of $\mathbf{L}$ with $\mathbf{2}$ and $\mathbf{3}$, respectively (Fig. 6). The rapid intermolecular ligand exchange observed for the larger Group 12 congeners is considerably more common for complexes of $\mathrm{d}^{10}$ metal ions, especially with low coordination number ligands. Significantly, the proton chemical shifts for $\mathbf{2}$ and $\mathbf{3}$ became invariant at $\left[\mathrm{M}\left(\mathrm{ClO}_{4}\right)_{2}\right] /[\mathbf{L}]>1$. Furthermore, excess $\mathrm{M}$ (II) permitted collection of ${ }^{1} \mathrm{H}$ NMR with sufficiently narrow peaks widths for detection of extensive heteronuclear coupling interactions between protons of $\mathbf{L}$ and the high natural abundance spin $I=1 / 2$ metal nuclei ${ }^{111 / 113} \mathrm{Cd}$ (Fig. $7 \mathrm{c}, \mathrm{d}$ ) and ${ }^{199} \mathrm{Hg}$ (Fig. 7e, f), providing definitive evidence for slow intermolecular exchange of $\mathbf{L}$. The $J_{\mathrm{MH}}$ observed for $\mathbf{3}$ were larger than those observed for $\mathbf{2}$, and extended over a greater number of intervening bonds, as observed previously for $\mathrm{Hg}$ (II) and $\mathrm{Cd}(\mathrm{II})$ complexes of related ligands.[19-22, 24, 35, 36] The ${ }^{199} \mathrm{Hg}$ couplings to $H_{c}$ and $H_{h}$ provide rare examples of five-bond coupling between these two nuclei in a coordination compound.[20, 22, 24]

The ${ }^{1} \mathrm{H}$ NMR spectra of $\mathbf{1}, \mathbf{2}$ and $\mathbf{3}$ under slow intermolecular ligand exchange conditions were investigated as a function of temperature to gain insight regarding intramolecular ligand reorganization (Fig. 7). The pyridyl protons of the three complexes were observed as sets of six resonances for symmetry related protons with modest temperature dependence $\left(<1 \mathrm{ppb} /{ }^{\circ} \mathrm{C}\right)$. The methylene protons had varying degrees of broadening consistent with conformational reorganization of metal-bound ligand on an intermediate rate relative to the chemical shift time scale. 
Dramatic differences in the appearance of the methylene proton resonances for the three complexes as a function of temperature indicated differences in intramolecular ligand reorganization rates. The downfield exchange averaged singlet methylene resonances for the complexes were consistently more narrow than the upfield singlet methylene resonance at $20^{\circ} \mathrm{C}$. The upfield methylene resonance ranged from slightly broadened to broadened to obscurity in the order $\mathbf{2}<\mathbf{3}<\mathbf{1}$. Significantly, four geminally coupled doublets $\left({ }^{2} J_{\mathrm{HH}}=16-18 \mathrm{~Hz}\right)$ were observed for the methylene protons of $\mathbf{1}$ under cryogenic conditions (Fig. 7b), consistent with the approximate $C_{2}$ symmetry of the solid-state structure (Fig. 2). Residual broadening of the methylene resonances was still evident at $-40{ }^{\circ} \mathrm{C}$ in $\mathrm{CD}_{3} \mathrm{CN}$ (Fig. $7 \mathrm{~b}$ ) and at $-80{ }^{\circ} \mathrm{C}$ in acetone- $d_{6}$ (data not shown), precluding detailed quantitative analysis of exchange rates. In contrast, under similar conditions slow exchange on the $\delta_{\mathrm{H}}$ and ${ }^{2} J_{\mathrm{HH}}$ time scales between asymmetric and twofold symmetric ligand environments was observed for $\left[\mathrm{ZnL}^{\prime}\right]\left(\mathrm{ClO}_{4}\right)_{2}$. Geminal coupling between the methylene protons of 3 at $-40{ }^{\circ} \mathrm{C}$ in $\mathrm{CD}_{3} \mathrm{CN}$ was also indicated by broad spectral features between 3.8-4.7 ppm (Fig. 7f). The downfield and upfield spectral features integrated to six protons and two protons, respectively. Using line fitting analysis, the very broad upfield feature was fit to a doublet with chemical shift $4.03 \mathrm{ppm}$ and a $15 \mathrm{~Hz}$ coupling constant. The downfield feature was fit to pairs of methylene protons with chemical shifts of 4.55 and $4.50 \mathrm{ppm}$ and an 11 $\mathrm{Hz}$ geminal coupling constant, along with a much broader upfield shoulder with approximate chemical shift 4.46 and $15 \mathrm{~Hz}$ geminal coupling constant. In contrast, the methylene proton resonances for 2 in $\mathrm{CD}_{3} \mathrm{CN}$ were broader at $-40{ }^{\circ} \mathrm{C}$ (Fig. 7d) than at $20^{\circ} \mathrm{C}$ (Fig. 7c), however neither set of protons had reach the coalescence point. Assuming $\mathbf{1}$ and $\mathbf{3}$ would have comparable peak widths under conditions of no exchange, differences in peak width at $-40{ }^{\circ} \mathrm{C}$ suggest $\mathbf{L}$ undergoes slower reorganization when bound to $\mathrm{Zn}$ (II) than when bound to $\mathrm{Hg}(\mathrm{II})$. Since the 
coalescence points for the methylene proton resonances of $\mathbf{2}$ were not experimentally accessible, we have no way of assessing $\Delta \delta_{\mathrm{H}},{ }^{2} J_{\mathrm{HH}}$ or peak widths as the slow exchange limit is approached and the relative rate of reorganization of $\mathbf{L}$ when bound to $\mathrm{Cd}(\mathrm{II})$ remains unclear. The potential influence of differential metal-perchlorate interactions on reorganization of metal bound $\mathbf{L}$ was not investigated directly, other than to note that variable temperature ${ }^{1} \mathrm{H}$ NMR behavior remained constant for $\mathbf{1}$ - $\mathbf{3}$ with 5-25\% excess $\mathrm{M}\left(\mathrm{ClO}_{4}\right)_{2}$ (data not shown).

\subsection{Correlation of Solid State and Solution State Characterizations}

One of the major challenges associated with investigating divalent Group 12 metal ions is controlling the donor atoms in the primary coordination sphere. All three metal ions tolerate coordination numbers up to eight and have a robust affinity for a variety of donor groups. The crystallographic forms of $\mathbf{1}$ and $\mathbf{3}$ have $\mathrm{N}_{3} \mathrm{~S}_{2}$ primary coordination spheres provided exclusively by one molecule of $\mathbf{L}$ while $\mathbf{2}$ had an additional bidentate perchlorate bound to $\mathrm{Cd}(\mathrm{II})$. The four published structurally characterized complexes of $\mathrm{Cd}(\mathrm{II})$ bound to a single ligand providing an $\mathrm{N}_{3} \mathrm{~S}_{2}$ donor set have coordination numbers ranging from six to eight.[37] The comparably sized $\mathrm{Hg}$ (II) ion has commonly had other atoms, including perchlorate oxygen,[38] bound to the metal with pentadentate $\mathrm{N}_{3} \mathrm{~S}_{2}$ ligands. However, the $\mathrm{N}_{3} \mathrm{~S}_{3}$ crown thioether variant of $\mathbf{L}$ formed a $\mathrm{Hg}$ (II) five coordinate complex ( $\tau=0.48$ ) with pendant sulfur.[39] Zinc(II) has a smaller ionic radius and there are eight structurally characterized complexes where a single $\mathrm{N}_{3} \mathrm{~S}_{2}$ donor ligand exclusively occupies the primary coordination sphere. However, complexes with other groups, including perchlorate,[40] bound to the metal ion are more common. In that context, it cannot be assumed that $\mathbf{1}$ and $\mathbf{3}$ remain exclusively five coordinate in solution. However, these complexes consistently had lower solubility in organic solvents and ligand chemical shifts that were shifted further downfield with respect to free ligand than $\mathbf{2}$, suggesting the relative concentrations of 
$[\mathrm{ML}]^{2+}$ and $\left[\mathrm{ML}\left(\mathrm{ClO}_{4}\right)\right]^{+}$were shifted towards the later with $\mathrm{Cd}(\mathrm{II})$ and the former with $\mathrm{Zn}(\mathrm{II})$ and $\mathrm{Hg}(\mathrm{II})$ under metal saturated conditions.

Based on the corkscrew conformation of $\mathbf{L}$, the three new complexes had geometries intermediate between trigonal bipyramidal and square pyramidal in the solid state as indicated by the $\tau$ parameter. For $\mathrm{d}^{10}$ metal ion complexes involving simple ligands, ligand relocation with interconversion of coordination geometries involves numerous simple angular distortions with very modest energy demands. In contrast, the short tethers between donor atoms in unbranched pentadentate $\mathbf{L}$ and other steric constraints impose an abridged mechanism requiring thioether inversion[41] to isomerize two pairs of symmetric $(\mathbf{5 a}, \mathbf{5 b})$ and asymmetric $(\mathbf{6 a}, \mathbf{6} \mathbf{b})$ enantiomers (Figure 8).[24] The three new complexes are capped (2), uncapped (3) and uncapped with the terminal pyridyl $\mathrm{N}$ displaced significantly from the basal plane towards the open position (1) variants of $\mathbf{5}$. In contrast, structurally characterized $\mathrm{Cd}(\mathrm{II})$ and $\mathrm{Hg}(\mathrm{II})$ complexes of $\mathbf{L}^{\prime}$ were square pyramidal with an apical terminal pyridyl $\mathbf{N}(6)$ and two perchlorate caps[24] while the $\mathrm{Zn}\left(\mathrm{ClO}_{4}\right)$ complex was an uncapped distorted trigonal bipyramid (5).[42] The methylene protons of $\mathbf{L}$ and $\mathbf{L}^{\prime}$ can act as reporters of solution state conformation producing up to four geminally coupled doublets in conformation $\mathbf{5}$, up to eight geminally coupled doublets in conformation $\mathbf{6}$ and a pair of singlets when conformational exchange is rapid on the chemical shift time scale.

The conformational behavior of structurally related ligands $\mathbf{L}$ and $\mathbf{L}^{\prime}$ were different in the Group 12 perchlorate coordination complexes. Solution studies suggested the $\mathrm{N}_{5}$ ligand $\left(\mathbf{L}^{\prime}\right)$ preferentially adopted an asymmetric conformation with all three metal ions in solution at ambient temperature as represented by $\mathbf{6}$.[24] No evidence for the symmetric $\mathbf{L}$ conformation associated with $\mathbf{5}$ was found for $\left[\mathrm{HgL}^{\prime}\right]^{2+}$, but a temperature-dependent equilibrium between the ligand conformations of $\mathbf{5}$ and $\mathbf{6}$ was suggested by the proton NMR behavior for the other Group 
12 metal ions. In contrast, no more than four methylene proton environments were observed for 1-3 suggesting solution and solid state conformation are comparable and the conformation of metal bound $\mathbf{L}$ associated with $\mathbf{6}$ is transient under accessible solution conditions. Intriguingly, the smaller, harder $\mathrm{Zn}$ (II) ion was most effective at imposing conformational stability on $\mathbf{L}$ and the softer $\mathrm{Hg}$ (II) ion was most effective at imposing conformational stability on $\mathbf{L}^{\prime}$. Additional studies will be needed to rationalize those differences.

\section{Conclusions}

Mixed donor ligand 2,6-bis([(2-pyridinylmethyl)thio]methyl)pyridine) was used to provide the first series of structurally characterized Group 12 metal ion complexes involving a common $\mathrm{N}_{3} \mathrm{~S}_{2}$ set of donor atoms. A similar approximately $C_{2}$ symmetric coiled conformation was adopted by $\mathbf{L}$ in $[\mathrm{ZnL}]\left(\mathrm{ClO}_{4}\right)_{2}(\mathbf{1}),\left[\mathrm{Cd} \mathbf{L}\left(\mathrm{ClO}_{4}\right)\right] \mathrm{ClO}_{4}(\mathbf{2})$ and $[\mathrm{HgL}]\left(\mathrm{ClO}_{4}\right)_{2}(\mathbf{3})$ despite differences in overall coordination number. In acetonitrile solution, the three Group 12 pentadentate ligand complexes were stable to intermolecular exchange with excess metal on the chemical shift time scale, and the $\mathrm{Zn}$ (II) complex was additionally stable to intermolecular exchange with excess ligand. All three complexes underwent rapid intramolecular reorganization at elevated temperatures. Under cryogenic conditions, slow intramolecular exchange conditions consistent with a predominantly symmetric ligand conformation were approached for $\mathbf{1}$ and $\mathbf{3}$. A ligand of modest complexity bound to Group 12 metal ions provided a rare example of metaldependent differences in the ensemble of conformations.

\section{Acknowledgements}

This work was supported in part by the US National Science Foundation Division of Chemistry under Grant 0315934. Purchases of the College of William \& Mary SMART Apex II 
diffractometer, Varian NMR and Agilent NMR were also partially supported by the U. S.

National Science Foundation. In addition, portions of this research were supported by a

Petroleum Research Fund of the American Chemical Society and The College of William \&

Mary. Additional support for undergraduate coworkers was provided by the ALSAM Foundation

and by a Howard Hughes Medical Institute grant through the Undergraduate Biological Sciences

Education Program to the College of William and Mary. 


\section{References}

[1] K. Kaur, R. Gupta, S.A. Saraf, S.K. Saraf, Compr. Rev. Food Sci. Food Saf. 13 (2014) 358-376.

[2] D. Wang, C.A. Fierke, Metallomics 5 (2013) 372-383.

[3] C.T. Chasapis, A.C. Loutsidou, C.A. Spiliopoulou, M.E. Stefanidou, Arch. Toxicol. 86 (2012) 521534.

[4] M.A. Aras, E. Aizenman, Antioxid. Redox Signaling 15 (2011) 2249-2263.

[5] B.F. Azevedo, L.B. Furieri, F.M. Pecanha, A.G. Wiggers, P.F. Vassallo, M.R. Simoes, J. Fiorim, P.

Rossi de Batista, M. Fioresi, L. Rossoni, I. Stefanon, M.J. Alonso, M. Salaices, D.V. Vassallo, J. Biomed.

Biotechnol. (2012) 949048, 949011 pp.

[6] V. Praveen Chakravarthi, J.A. Pradeep Kiran, M. Bhaskar, Int. J. Pharm. Biol. Sci. 2 (2012) 235-246.

[7] T.W. Lane, F.M.M. Morel, Proc. Natl. Acad. Sci. 97 (2000) 4627-4631.

[8] H. Park, B. Song, F.M.M. Morel, Environ. Microbiol. 9 (2007) 403-413.

[9] L. Tang, R. Qiu, Y. Tang, S. Wang, Metallomics 6 (2014) 1313-1323.

[10] S.K. Sharma, P. Goloubinoff, P. Christen, Biochem. Biophys. Res. Commun. 372 (2008) 341-345.

[11] H. Kaluarachchi, J.F. Siebel, S. Kaluarachchi-Duffy, S. Krecisz, D.E.K. Sutherland, M.J. Stillman, D.B. Zamble, Biochemistry 50 (2011) 10666-10677.

[12] H. Kozlowski, S. Potocki, M. Remelli, M. Rowinska-Zyrek, D. Valensin, Coord. Chem. Rev. 257 (2013) 2625-2638.

[13] D.-J. Yang, S. Shi, T.-M. Yao, L.-N. Ji, Bull. Chem. Soc. Jpn. 84 (2011) 1362-1367.

[14] J. Mutter, J. Naumann, C. Sadaghiani, R. Schneider, H. Walach, Neuroendocrinol. Lett. 25 (2004)

331-339.

[15] G. Notarachille, E. Galluci, S. Micelli, D. Meleleo, J. Environ. Chem. Ecotoxicol. 3 (2011) 309-319.

[16] U. Heinz, L. Hemmingsen, M. Kiefer, H.-W. Adolph, Chemistry--A European Journal 15 (2009) 7350-7358.

[17] B. Wang, Y. Du, Oxid. Med. Cell. Longev. 2013, Article ID 898034 (2013) 12 pages.

[18] A. Carocci, N. Rovito, M.S. Sinicripi, G. Genchi, Rev. Environ. Contam. Toxicol. 229 (2014) 1-18.

[19] D.C. Bebout, W. Lai, S.M. Stamps, S.M. Berry, R.J. Butcher, Polyhedron 27 (2008) 1591-1600.

[20] D.C. Bebout, W. Lai, S.M. Stamps, S.M. Berry, R.J. Butcher, Main Group Chem. 6 (2007) 155-168.

[21] W. Lai, S.M. Berry, D.C. Bebout, R.J. Butcher, Inorg. Chem. 45 (2006) 571-581.

[22] S.M. Berry, D.C. Bebout, R.J. Butcher, Inorg. Chem. 44 (2005) 27-39.

[23] D.C. Bebout, S.M. Berry, Struct. Bond. 120 (2006) 81-105.

[24] B.J. Carra, S.M. Berry, R.D. Pike, D.C. Bebout, Dalton Trans. 42 (2013) 14424-14431.

[25] G.R. Newkome, V.K. Gupta, F.R. Fronczek, S. Pappalardo, Inorg. Chem. 23 (1984) 2400-2408.

[26] W.C. Wosley, J. Chem. Educ. 50 (1973) A335.

[27] K.N. Raymond, Chem. Eng. News 61 (1983) 4.

[28] G.M. Sheldrick, Acta Crystallogr., Sect. A: Found. Crystallogr. 64 (2008) 112-122.

[29] C.B. Hübschle, G.M. Sheldrick, B. Dittrich, J. Appl. Crystallogr. 44 (2011) 1281-1284.

[30] A.W. Addison, T.N. Rao, J. Reedijk, J. Van Rijn, G.C. Verschoor, J. Chem. Soc., Dalton Trans. (1984) 1349-1356.

[31] S.-Z. Hu, Z.-H. Zhou, B.E. Robertson, Z. Kristallogr. 224 (2009) 375-383.

[32] P.L. Caradoc-Davies, L.R. Hanton, K. Lee, Chem. Commun. (2000) 783-784.

[33] D.C. Bebout, D.E. Ehmann, J.C. Trinidad, K.K. Crahan, M.E. Kastner, D. Parrish, Inorg. Chem. 36 (1997) 4257-4264.

[34] D.C. Bebout, A.E. DeLanoy, D.E. Ehmann, M.E. Kastner, D.A. Parrish, R.J. Butcher, Inorg. Chem. 37 (1998) 2952-2959.

[35] E.V. Bowers, G.S. Murphy, S.N. Till, C.J. VandenBussche, M.M. Yaroschak, R.D. Pike, R.J.

Butcher, D.C. Bebout, Dalton Trans. 43 (2014) 16475-16485. 
[36] D.C. Bebout, S.W. Stokes, R.J. Butcher, Inorg. Chem. 38 (1999) 1126-1133.

[37] Cambridge Structural Database (v 5.36 updated November 2014), in, Cambridge Structural Database (v 5.36 updated November 2014).

[38] L. Huang, Y. Peng, Z. Li, Z. Wei, D.L. Hughes, X. Zeng, Q. Luo, X. Liu, Inorg. Chim. Acta 363 (2010) 2664.

[39] M. Vetrichelvan, Y.-H. Lai, K.F. Mok, Eur. J. Inorg. Chem. (2004) 2086-2095.

[40] D.C. Liles, M. McPartlin, P.A. Tasker J. Chem. Soc., Dalton Trans. (1987) 1631-1636.

[41] L. Baradello, S.L. Schiavo, F. Nicolo, S. Lanza, G. Alibrandi, G. Tresoldi, Eur. J. Inorg. Chem. (2004) 3358-3369.

[42] T. Darbre, C. Dubs, E. Rusanov, H. Stoeckli-Evans, Eur. J. Inorg. Chem. (2002) 3284-3291. 
Table 1. Crystallographic Data for $\mathbf{L}$, $[\mathrm{ZnL}]\left(\mathrm{ClO}_{4}\right)_{2}(\mathbf{1})$, $\left[\mathrm{Cd} \mathbf{L}\left(\mathrm{ClO}_{4}\right)\right] \mathrm{ClO}_{4}(\mathbf{2})$ and $[\mathrm{HgL}]\left(\mathrm{ClO}_{4}\right)_{2}$ (3)

\begin{tabular}{|c|c|c|c|c|}
\hline & $\mathbf{L}$ & 1 & 2 & 3 \\
\hline Empirical Formula & $\mathrm{C}_{19} \mathrm{H}_{19} \mathrm{~N}_{3} \mathrm{~S}_{2}$ & $\mathrm{C}_{19} \mathrm{H}_{19} \mathrm{Cl}_{2} \mathrm{~N}_{3} \mathrm{O}_{8} \mathrm{~S}_{2} \mathrm{Zn}$ & $\mathrm{C}_{19} \mathrm{H}_{19} \mathrm{CdCl}_{2} \mathrm{~N}_{3} \mathrm{O}_{8} \mathrm{~S}_{2}$ & $\mathrm{C}_{19} \mathrm{H}_{19} \mathrm{Cl}_{2} \mathrm{HgN}_{3} \mathrm{O}_{8} \mathrm{~S}_{2}$ \\
\hline Formula mass $\left[\mathrm{g} \mathrm{mol}^{-1}\right]$ & 353.49 & 617.76 & 664.79 & 752.98 \\
\hline Crystal Size $\left[\mathrm{mm}^{3}\right]$ & $0.39 \times 0.16 \times 0.06$ & $0.24 \times 0.24 \times 0.21$ & $0.57 \times 0.30 \times 0.29$ & $0.21 \times 0.11 \times 0.09$ \\
\hline Crystal System & Orthorhombic & Monoclinic & Monoclinic & Orthorhombic \\
\hline Space Group & Pna2 $_{1}$ & $P 2_{1} / n$ & $P 2_{1} / c$ & $I b c a$ \\
\hline$a[\AA]$ & $12.9828(4)$ & $16.6514(2)$ & $7.3214(5)$ & $13.78080(10)$ \\
\hline$b[\AA]$ & $6.4338(2)$ & $8.49690(10)$ & $33.811(2)$ & $14.8695(2)$ \\
\hline$c[\AA]$ & $21.0820(5)$ & $16.8825(2)$ & $9.8343(7)$ & $24.2789(3)$ \\
\hline$\beta\left[\left[^{\circ}\right]\right.$ & 90 & $98.9630(10)$ & $107.102(3)$ & 90 \\
\hline $\mathrm{V}\left[\AA^{3}\right]$ & $1760.95(9)$ & $2359.46(15)$ & $2326.8(3)$ & $4975.08(10)$ \\
\hline $\mathrm{Z}$ & 4 & 4 & 4 & 8 \\
\hline Radiation (monochromatic) & $\mathrm{Cu} \mathrm{K} \alpha$ & $\mathrm{Cu} \mathrm{K} \alpha$ & $\mathrm{Cu} \mathrm{K} \alpha$ & $\mathrm{Cu} \mathrm{K} \alpha$ \\
\hline $\mathrm{T}[\mathrm{K}]$ & $100(2)$ & $296(2)$ & $100(2)$ & $296(2)$ \\
\hline$\rho_{\text {calcd }}\left[\mathrm{g} \mathrm{cm}^{-3}\right]$ & 1.333 & 1.739 & 1.898 & 2.011 \\
\hline$\lambda[\AA]$ & 1.54178 & 1.54178 & 1.54178 & 1.54178 \\
\hline$\mu\left[\mathrm{mm}^{-1}\right]$ & 2.767 & 5.659 & 11.792 & 15.098 \\
\hline Measured reflections & 13265 & 25814 & 22464 & 26860 \\
\hline Independent reflections $\left[\mathrm{R}_{(\mathrm{int})}\right]$ & $2992[0.0419]$ & $4157[0.0474]$ & $4075[0.0524]$ & $2219[0.1547]$ \\
\hline $\begin{array}{l}\text { Completeness of data }(\theta= \\
\left.67.000^{\circ}\right)\end{array}$ & $99.8 \%$ & $98.8 \%$ & $98.1 \%$ & $100 \%$ \\
\hline Data / restraints / parameters & $2992 / 1 / 218$ & $4157 / 0$ / 326 & $4075 / 0 / 316$ & $2219 / 145181$ \\
\hline $\mathrm{R} 1^{a}, \mathrm{wR} 2^{b}[I>2 \sigma(I)]$ & $0.0571,0.1545$ & $0.0486,0.1382$ & $0.0525,0.1291$ & $0.0637,0.1921$ \\
\hline $\mathrm{R} 1^{a}, \mathrm{wR} 2^{b}$ (all data) & $0.586,0.1566$ & $0.0519,0.1408$ & $0.0528,0.1292$ & $0.0822,0.2113$ \\
\hline GOOF & 1.087 & 1.046 & 1.369 & 1.027 \\
\hline
\end{tabular}


Table 2. Selected bond lengths $(\AA)$ and bond angles $\left(^{\circ}\right)$ for $[\mathrm{ZnL}]\left(\mathrm{ClO}_{4}\right)_{2} \quad$ (1), $\left[\mathrm{Cd} \mathbf{L}\left(\mathrm{ClO}_{4}\right)\right]\left(\mathrm{ClO}_{4}\right)(\mathbf{2})$, and $[\mathrm{HgL}]\left(\mathrm{ClO}_{4}\right)_{2}(\mathbf{3})$.

\begin{tabular}{|c|c|c|c|}
\hline & 1 & 2 & $3^{\mathrm{a}}$ \\
\hline M1-N1 & 2.024(3) & $2.310(5)$ & $2.258(11)$ \\
\hline M1-N2 & $2.095(3)$ & $2.464(5)$ & $2.387(14)$ \\
\hline M1-N3 & 2.019(3) & $2.256(5)$ & \\
\hline M1-S1 & $2.5108(10)$ & $2.6489(17)$ & $2.632(3)$ \\
\hline M1-S2 & $2.4706(9)$ & $2.7225(17)$ & \\
\hline M1-O1 & & $2.585(5)$ & \\
\hline M1-O2 & & $2.591(5)$ & \\
\hline N1-M1-N2 & $122.72(12)$ & $78.66(19)$ & $113.8(2)$ \\
\hline N1-M1-N3 & $127.19(12)$ & $165.7(2)$ & $132.4(5)$ \\
\hline N1-M1-S1 & $81.35(9)$ & $77.81(14)$ & $78.9(3)$ \\
\hline N1-M1-S2 & $99.80(9)$ & $111.64(14)$ & 114.4(3) \\
\hline N1-M1-O1 & & $81.39(17)$ & \\
\hline N1-M1-O2 & & $78.39(17)$ & \\
\hline N2-M1-N3 & $110.08(11)$ & $115.56(19)$ & \\
\hline N2-M1-S1 & $82.28(8)$ & $77.81(14)$ & $74.24(8)$ \\
\hline N2-M1-S2 & $84.87(8)$ & $72.85(14)$ & \\
\hline N2-M1-O1 & & $140.86(17)$ & \\
\hline N2-M1-O2 & & $149.16(17)$ & \\
\hline N3-M1-S1 & $105.97(8)$ & $103.05(14)$ & \\
\hline N3-M1-S2 & $85.14(8)$ & $75.73(15)$ & \\
\hline N3-M1-O1 & & $87.46(18)$ & \\
\hline N3-M1-O2 & & $87.84(18)$ & \\
\hline S1-M1-S2 & $165.30(4)$ & $146.24(5)$ & $148.48(15)$ \\
\hline S1-M1-O1 & & $129.82(11)$ & \\
\hline S1-M1-O2 & & $77.43(11)$ & \\
\hline S2-M1-O1 & & $83.93(11)$ & \\
\hline $\mathrm{S} 2-\mathrm{M} 1-\mathrm{O} 2$ & & $135.44(11)$ & \\
\hline O1-M1-O2 & & $53.75(15)$ & \\
\hline
\end{tabular}

${ }^{a}$ Symmetry transformations used to generate equivalent atoms: \#1 -x+1,-y+1/2,z+0; \#2 $\mathrm{x}+3 / 2, \mathrm{y}+0,-\mathrm{z}+0 ; \# 3 \mathrm{x}+0,-\mathrm{y}+1,-\mathrm{z}+1 / 2$ 


\section{List of Captions}

Figure 1. Ortep structure of $\mathbf{L}$, showing the crystallographic numbering scheme. Thermal ellipsoids are shown at $50 \%$ probability.

Figure 2. Ortep structure of $[\mathrm{ZnL}]^{2+}$ (cation of $\mathbf{1}$ ), showing the crystallographic numbering scheme. Thermal ellipsoids are shown at $50 \%$ probability.

Figure 3. Ortep structure of $\left[\mathrm{Cd} \mathbf{L}\left(\mathrm{ClO}_{4}\right)\right]^{+}$(cation of 2), showing the crystallographic numbering scheme. Thermal ellipsoids are shown at 50\% probability.

Figure 4. Ortep structure of $[\mathrm{HgL}]^{2+}$ (cation of $\mathbf{3}$ ), showing the crystallographic numbering scheme. Thermal ellipsoids are shown at $30 \%$ probability.

Figure 5. ${ }^{1} \mathrm{H}$ NMR $\left(400 \mathrm{MHz}, \mathrm{CD}_{3} \mathrm{CN}, 20{ }^{\circ} \mathrm{C}\right)$ of nominally $2 \mathrm{mM} \mathrm{L}$ with added $\mathrm{Zn}\left(\mathrm{ClO}_{4}\right)_{2} \cdot 6 \mathrm{H}_{2} \mathrm{O}$ with approximate $[\mathrm{Zn}(\mathrm{II})] /[\mathrm{L}]$ of (a) 0.25 , (b) 0.50 , (c) 0.75 , (d) 1.00 , and (e) 1.25. Proton resonance associated with free $\mathbf{L}$ and $\mathbf{1}$ are labeled above and below the spectra, respectively.

Figure 6. Observed chemical shifts for $\mathrm{H}_{\mathrm{c}}$ of $\mathbf{L}$ as a function of nominal $\left[\mathrm{Cd}\left(\mathrm{ClO}_{4}\right)_{2}\right] /[\mathbf{L}](\boldsymbol{\square})$ and $\left[\mathrm{Hg}\left(\mathrm{ClO}_{4}\right)_{2}\right] /[\mathbf{L}](\bullet)$ ratios in $\mathrm{CD}_{3} \mathrm{CN}$ at $20^{\circ} \mathrm{C}$. Linear trendlines are shown for $\left[\mathrm{M}\left(\mathrm{ClO}_{4}\right)_{2}\right] /[\mathbf{L}]<$ 1. The open square and circle correspond to the chemical shift observed for $\mathrm{H}_{\mathrm{c}}$ of $\mathbf{2}$ and $\mathbf{3}$, respectively, under comparable conditions. Chemical shift trends for the other protons of $\mathbf{L}$ as a function of $\left[\mathrm{Cd}\left(\mathrm{ClO}_{4}\right)_{2}\right]$ and $\left[\mathrm{Hg}\left(\mathrm{ClO}_{4}\right)_{2}\right]$ are shown in Figures $\mathrm{S} 7$ and S8, respectively.

Figure 7. Selected ${ }^{1} \mathrm{H} \mathrm{NMR}\left(400 \mathrm{MHz}, \mathrm{CD}_{3} \mathrm{CN}\right.$, nominally $2 \mathrm{mM}$ ) of complexes: 1 at (a) $60{ }^{\circ} \mathrm{C}$ and (b) $-40{ }^{\circ} \mathrm{C} ; 2$ with $\sim 10 \%$ excess $\mathrm{Cd}\left(\mathrm{ClO}_{4}\right)_{2} \cdot 6 \mathrm{H}_{2} \mathrm{O}$ at (c) $20{ }^{\circ} \mathrm{C}$ and (d) $-40{ }^{\circ} \mathrm{C} ; \mathbf{3}$ with $\sim 10 \%$ 
excess $\mathrm{Hg}\left(\mathrm{ClO}_{4}\right)_{2} \cdot 6 \mathrm{H}_{2} \mathrm{O}$ at (e) $20{ }^{\circ} \mathrm{C}$ and (f) $-40{ }^{\circ} \mathrm{C}$. Aromatic proton labels are provided below their resonances in the lower temperature spectrum for each complex and shifted downfield at higher temperature. Heteronuclear ${ }^{3} J\left({ }^{111 / 113} \mathrm{Cd}^{1} \mathrm{H}\right)$ and ${ }^{3} J\left({ }^{199} \mathrm{Hg}{ }^{1} \mathrm{H}\right)$ couplings are highlighted in (c) and (d), respectively, with comparable couplings observed at $-40{ }^{\circ} \mathrm{C}$ unless obscured by peak broadening. Unlabeled peaks in the region $\delta 3.8-4.8$ ppm are associated with $\mathrm{H}_{\mathrm{e}}$ and $\mathrm{H}_{\mathrm{f}}$.

Figure 8. Octahedral edge configuration schematic of proposed conformational isomerization for divalent Group 12 perchlorate complexes of $\mathbf{L}$. The sixth coordinate position may be empty or occupied by perchlorate or solvent; possible capping of triangular faces not shown for clarity. Letters $\mathrm{a}$ and $\mathrm{b}$ are used to denote enantiomers. Blue circles $=\mathrm{N} 1 \& \mathrm{~N} 3 ;$ Red diamonds $=\mathrm{S} 1 \&$ S2; White circle $=\mathrm{N} 2$. 
<smiles>c1ccc(CSCc2cccc(CSCc3ccccn3)n2)nc1</smiles>
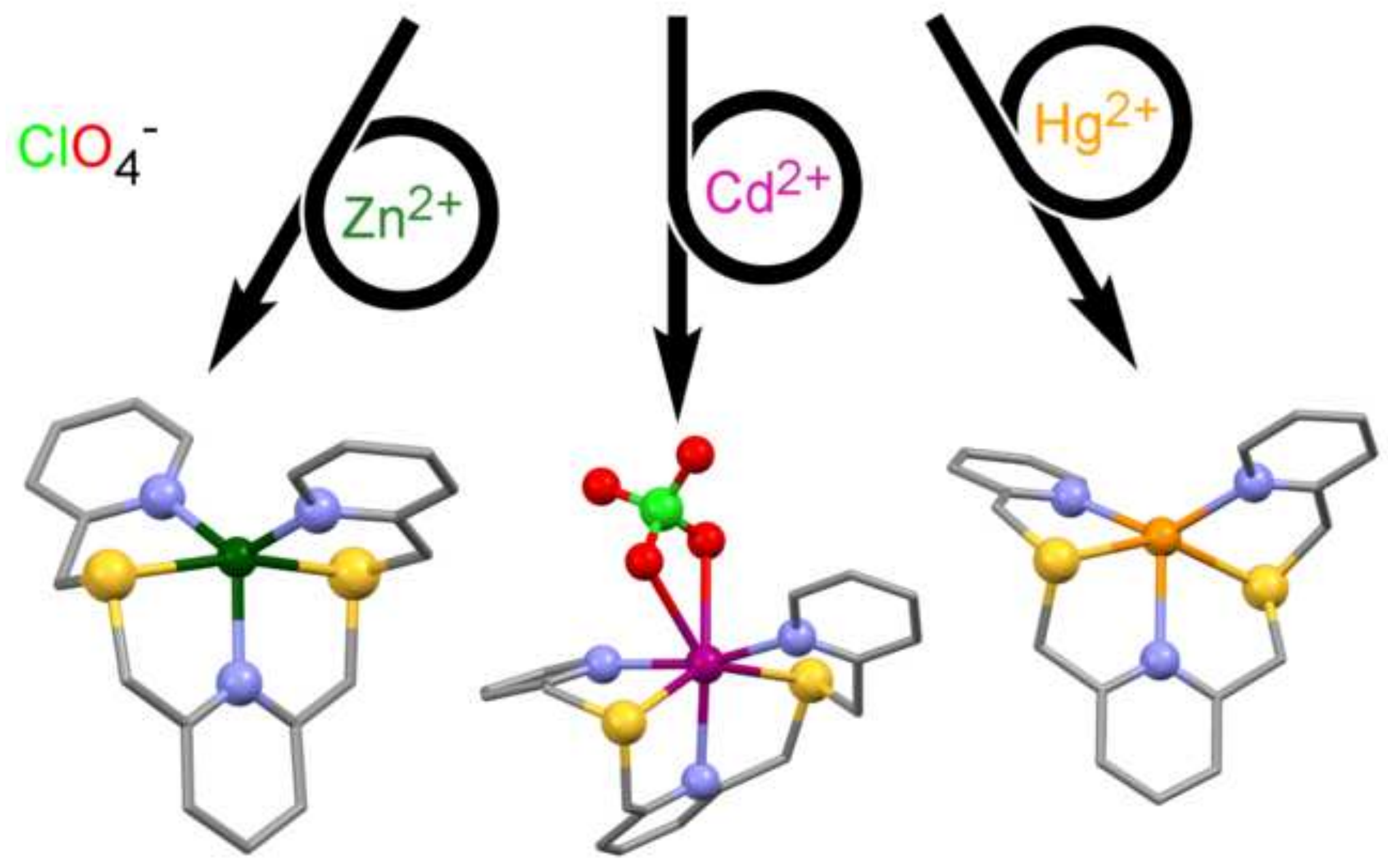
<smiles>c1ccc(CNCc2cccc(CNCc3ccccn3)n2)nc1</smiles>

$L^{\prime}$

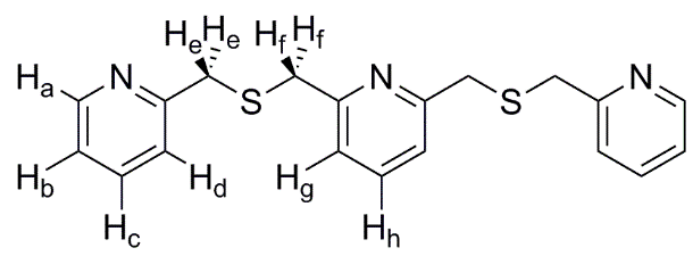

L

Scheme 1. Pentadentate ligands

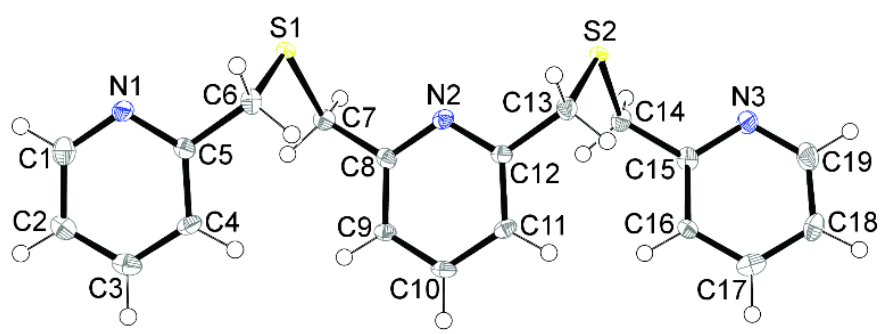

Figure 1. Ortep structure of $\mathbf{L}$, showing the crystallographic numbering scheme. Thermal ellipsoids are shown at $50 \%$ probability.

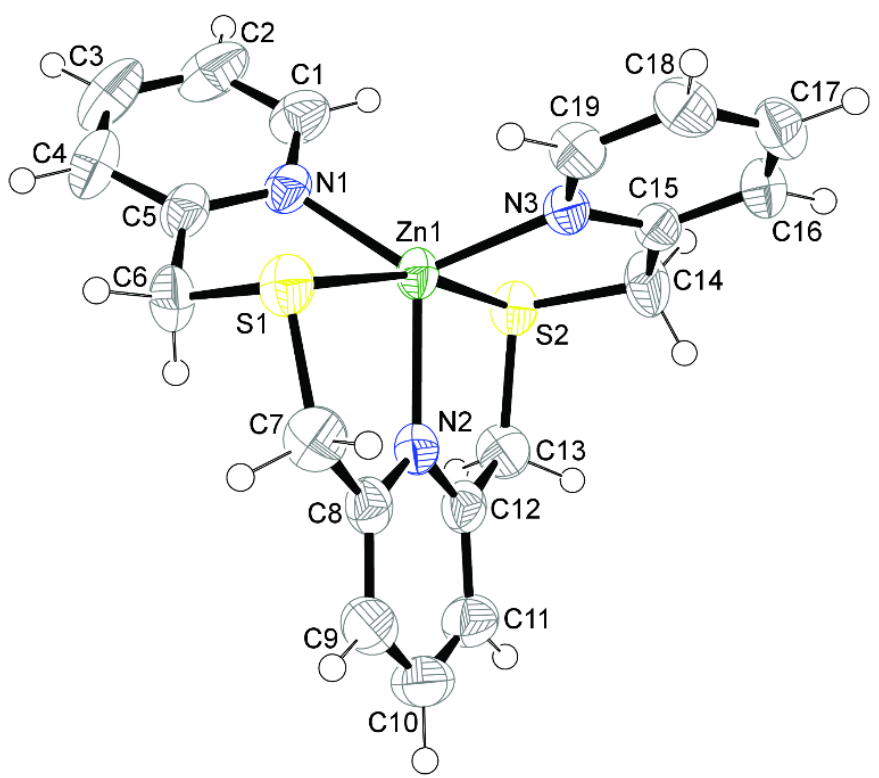

Figure 2. Ortep structure of $[\mathrm{ZnL}]^{2+}$ (cation of $\mathbf{1}$ ), showing the crystallographic numbering scheme. Thermal ellipsoids are shown at $50 \%$ probability. 


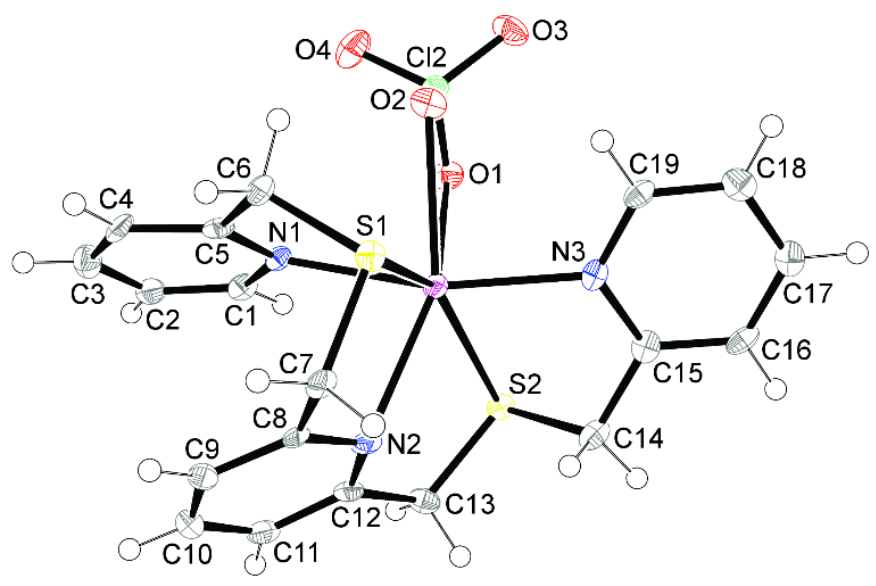

Figure 3. Ortep structure of $\left[\mathrm{Cd} \mathbf{L}\left(\mathrm{ClO}_{4}\right)\right]^{+}$(cation of 2), showing the crystallographic numbering scheme. Thermal ellipsoids are shown at $50 \%$ probability.

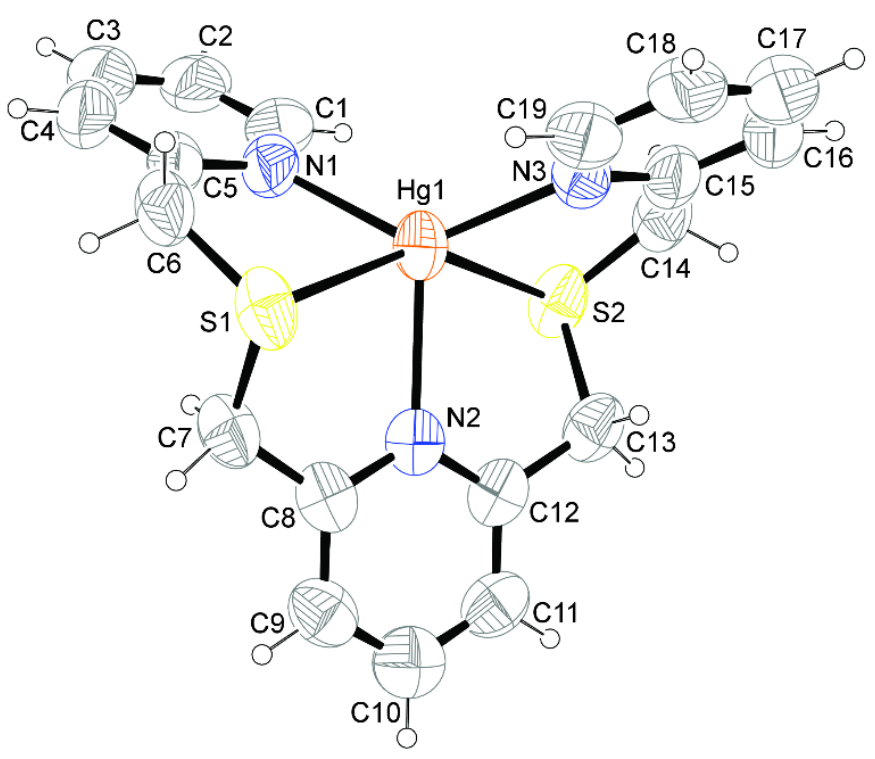

Figure 4. Ortep structure of $[\mathrm{HgL}]^{2+}$ (cation of $\mathbf{3}$ ), showing the crystallographic numbering scheme. Thermal ellipsoids are shown at $30 \%$ probability. 


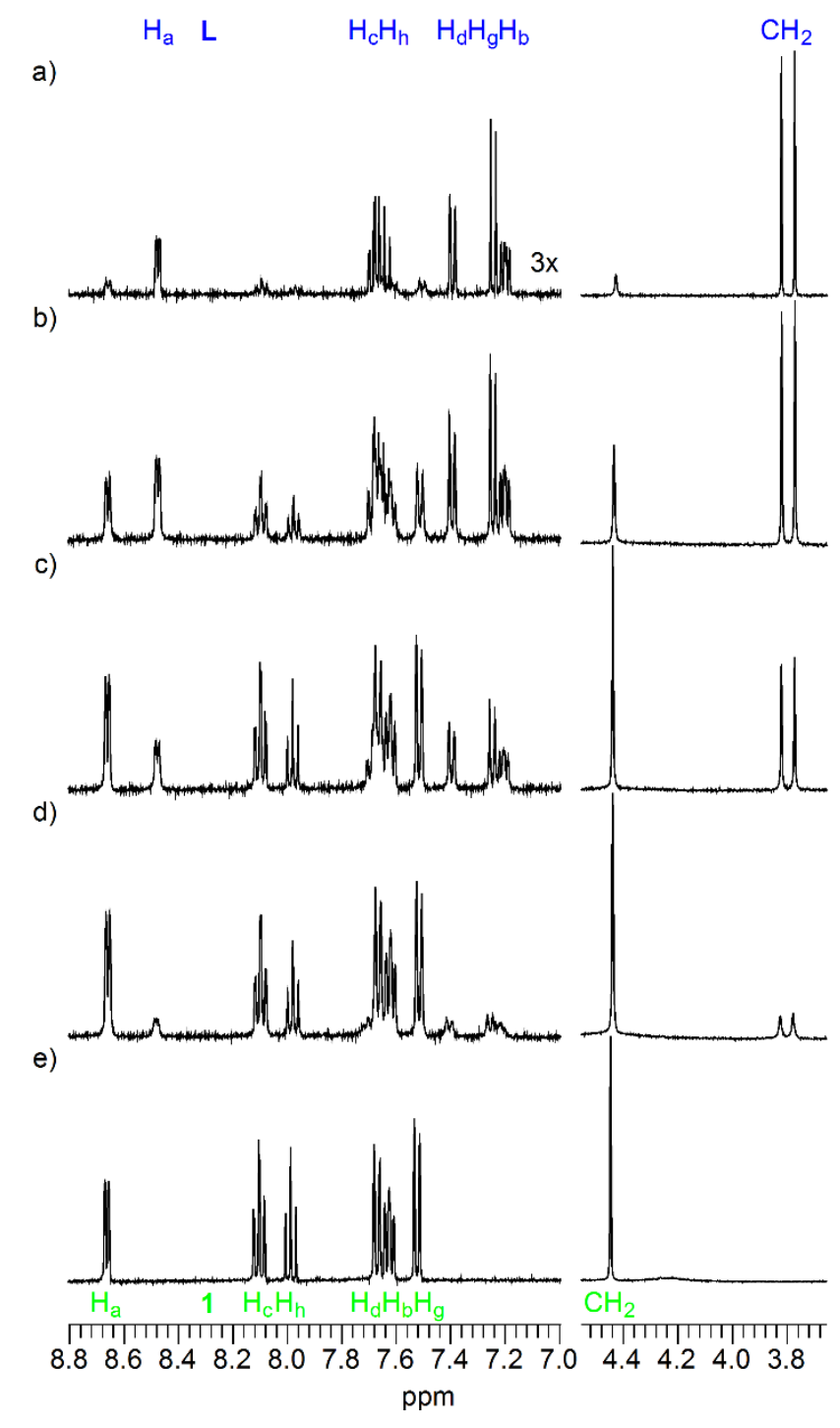

Figure 5. ${ }^{1} \mathrm{H}$ NMR $\left(400 \mathrm{MHz}, \mathrm{CD}_{3} \mathrm{CN}, 20{ }^{\circ} \mathrm{C}\right)$ of nominally $2 \mathrm{mM} \mathrm{L}$ with added $\mathrm{Zn}\left(\mathrm{ClO}_{4}\right)_{2} \cdot 6 \mathrm{H}_{2} \mathrm{O}$ with approximate $[\mathrm{Zn}(\mathrm{II})] /[\mathrm{L}]$ of (a) 0.25 , (b) 0.50 , (c) 0.75 , (d) 1.00 , and (e) 1.25. Proton resonance associated with free $\mathbf{L}$ and $\mathbf{1}$ are labeled above and below the spectra, respectively. The aromatic region of each spectrum is enlarged to show details. 


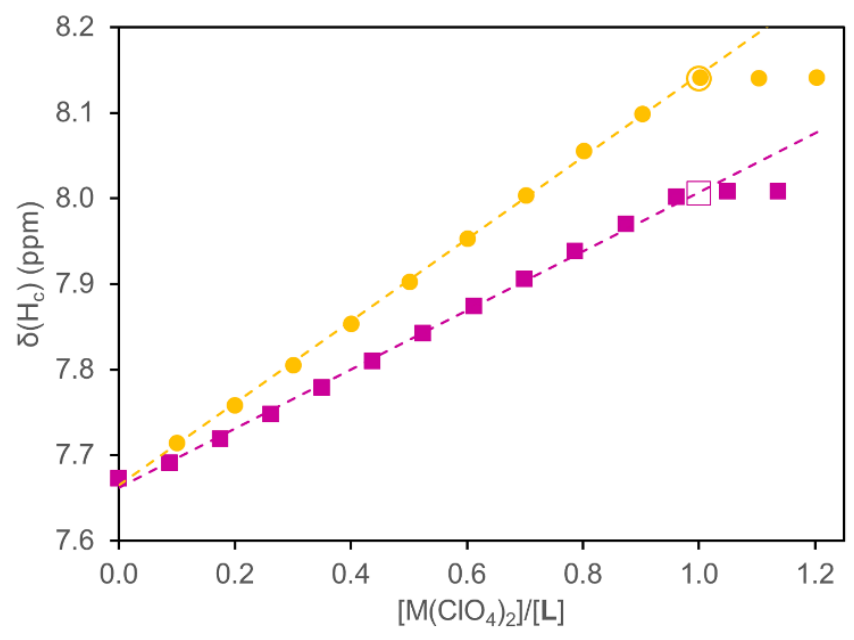

Figure 6. Observed chemical shifts for $\mathrm{H}_{\mathrm{c}}$ of $\mathbf{L}$ as a function of nominal $\left[\mathrm{Cd}\left(\mathrm{ClO}_{4}\right)_{2}\right] /[\mathbf{L}](\boldsymbol{\square})$ and $\left[\mathrm{Hg}\left(\mathrm{ClO}_{4}\right)_{2}\right] /[\mathbf{L}](\bullet)$ ratios in $\mathrm{CD}_{3} \mathrm{CN}$ at $20{ }^{\circ} \mathrm{C}$. Linear trendlines are shown for $\left[\mathrm{M}\left(\mathrm{ClO}_{4}\right)_{2}\right] /[\mathbf{L}]<$ 1. The open square and circle correspond to the chemical shift observed for $\mathrm{H}_{\mathrm{c}}$ of $\mathbf{2}$ and $\mathbf{3}$, respectively, under comparable conditions. Chemical shift trends for the other protons of $\mathbf{L}$ as a function of $\left[\mathrm{Cd}\left(\mathrm{ClO}_{4}\right)_{2}\right]$ and $\left[\mathrm{Hg}\left(\mathrm{ClO}_{4}\right)_{2}\right]$ are shown in Figures S7 and S8, respectively. 


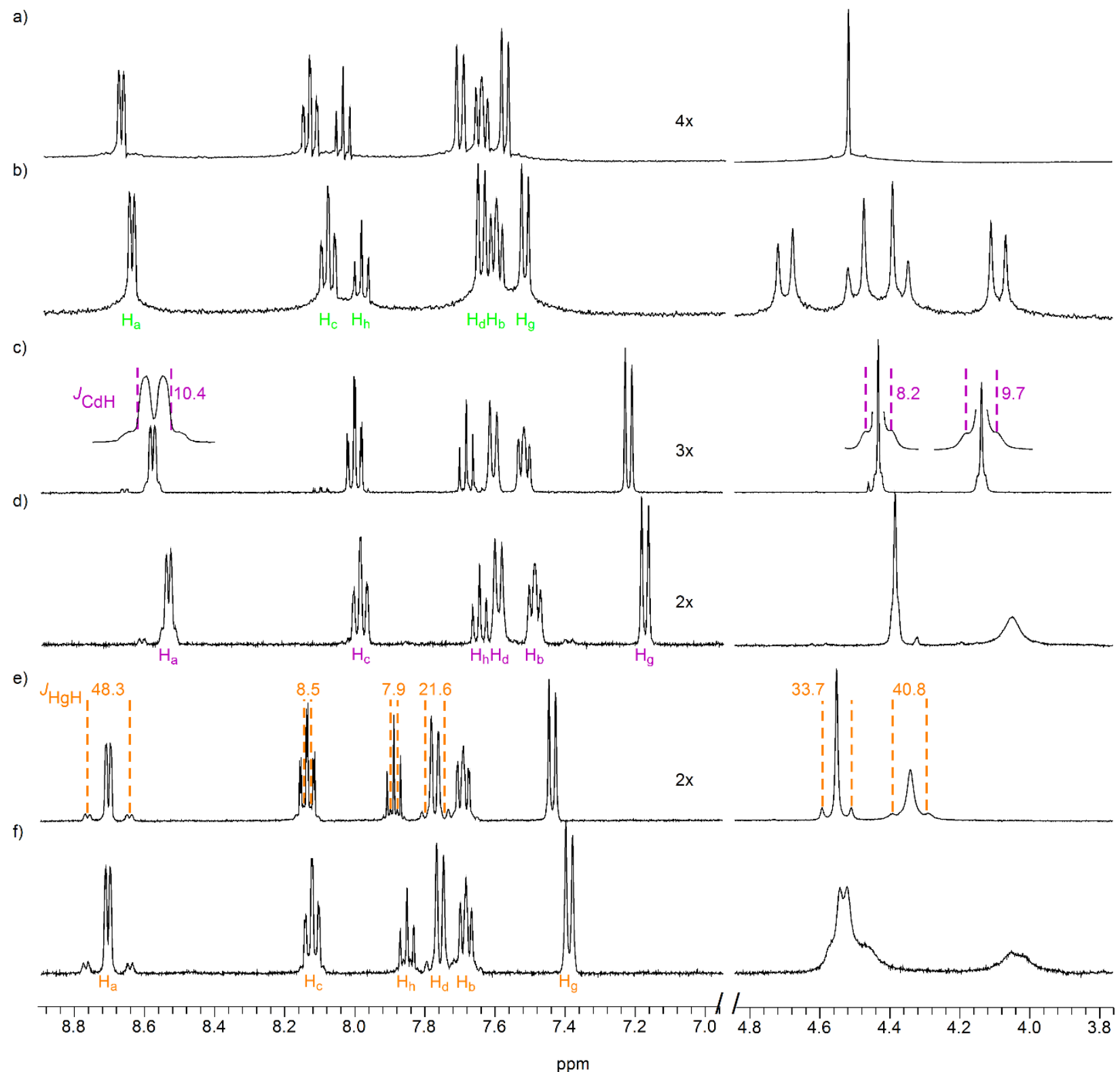

Figure 7. Selected ${ }^{1} \mathrm{H}$ NMR (400 MHz, $\mathrm{CD}_{3} \mathrm{CN}$, nominally $2 \mathrm{mM}$ ) of complexes: 1 at (a) $60{ }^{\circ} \mathrm{C}$ and (b) $-40{ }^{\circ} \mathrm{C} ; 2$ with $\sim 10 \%$ excess $\mathrm{Cd}\left(\mathrm{ClO}_{4}\right)_{2} \cdot 6 \mathrm{H}_{2} \mathrm{O}$ at (c) $20{ }^{\circ} \mathrm{C}$ and (d) $-40{ }^{\circ} \mathrm{C} ; \mathbf{3}$ with $\sim 10 \%$ excess $\mathrm{Hg}\left(\mathrm{ClO}_{4}\right)_{2} \cdot 6 \mathrm{H}_{2} \mathrm{O}$ at (e) $20{ }^{\circ} \mathrm{C}$ and (f) $-40{ }^{\circ} \mathrm{C}$. Aromatic proton labels are provided below their resonances in the lower temperature spectrum for each complex and shifted downfield at higher temperature. Heteronuclear ${ }^{3} J\left({ }^{111 / 113} \mathrm{Cd}^{1} \mathrm{H}\right)$ and ${ }^{3} J\left({ }^{199} \mathrm{Hg}^{1} \mathrm{H}\right)$ couplings are highlighted in (c) and (d), respectively, with comparable couplings observed at $-40{ }^{\circ} \mathrm{C}$ unless obscured by peak broadening. Unlabeled peaks in the region $\delta 3.8-4.8 \mathrm{ppm}$ are associated with $\mathrm{H}_{\mathrm{e}}$ and $\mathrm{H}_{\mathrm{f}}$. 


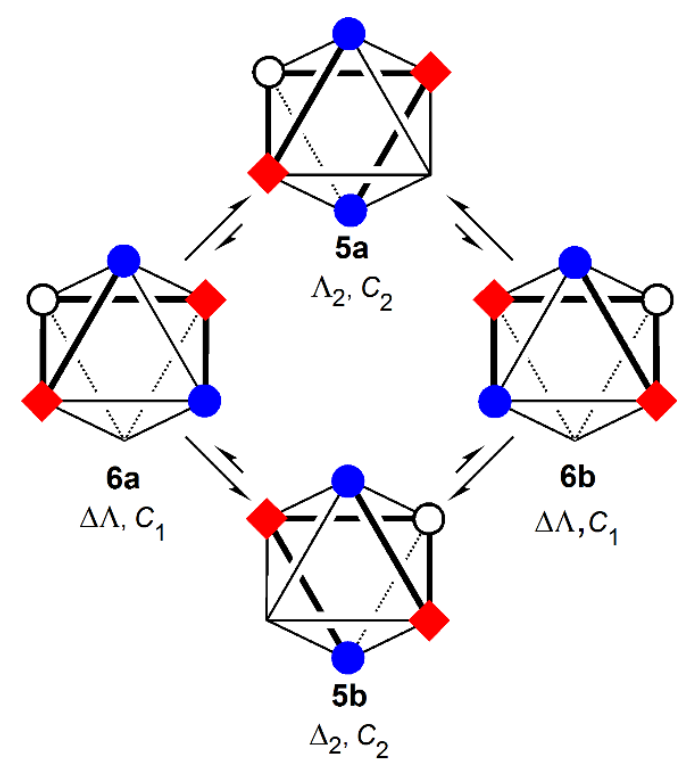

Figure 8. Octahedral edge configuration schematic of proposed conformational isomerization for divalent Group 12 perchlorate complexes of $\mathbf{L}$. The sixth coordinate position may be empty or occupied by perchlorate or solvent; possible capping of triangular faces not shown for clarity. Letters $\mathrm{a}$ and $\mathrm{b}$ are used to denote enantiomers. Blue circles $=\mathrm{N} 1 \& \mathrm{~N} 3 ;$ Red diamonds $=\mathrm{S} 1 \&$ S2; White circle $=\mathrm{N} 2$. 